\title{
MULTIPLE TRANSFUSIONS;
}

\author{
FREQUENCY OF ANTI-HEPATITIS C VIRUS (HCV) IN CHILDREN
}

\author{
Mr. Muhamamd Akram, Mr. Younas Bajwa, Dr. M. Nawaz Ch., Dr. Muhammad Asif.
}

ABSTRACT... Background: Multiple transfusions in patients of thalassemia who are conventionally treated by a regular transfusion regimen. Though regular blood transfusion improves the overall survival of patients with thalassemia, it carries a definite risk of infection with blood-borne viruses. The present study was carried out to estimate the real frequency of hepatitis $\mathrm{C}$ virus (HCV) among Pakistani thalassemic patients, and determine the infection-associated risk factors in these patients. Objective: To determine the frequency of antiHCV in children with multiple transfusions. Setting: Shalimar Hospital, Lahore. The samples were collected from Children Hospital, Mayo Hospital and Fatimid Foundation; Lahore. Period: June 2012 to Nov 2012. Subjects \& Methods: One hundred blood samples were collected from the children with multiple transfusions. Two to three $\mathrm{ml}$ of blood was taken from each multiply transfused child who had received more than two blood transfusions. Serum was separated from each sample by centrifugation at 6000 rpm for 5 minutes. After serum separation, all the samples were stored at $-80^{\circ} \mathrm{C}$. The HCV antibody can be detected by anti-HCV Rapid Test but third or fourth generation enzyme linked immunosorbent assay (ELISA) is considered a better indicator of the seropositivity of this antibody. Results: The ages ranged from 6 months to $>12$ years. The mean age of children in the study was $6.17 \pm 4.13$ years. There were 70 were males and 30 were females. Male to female ratio is 2.3:1. There are 58 thalassemic children, 27 different types of leukemia and 11 are aplastic anemia. Two children are with neuroblastoma while one each with thrombobasthenia and CDA-1. Conclusions: We concluded that a very high HCV prevalence which calls for adoption of stricter donor selection criteria, rigid implementation of quality control measures and use of more sensitive and specific techniques for HCV testing.

Key words: Frequency, Anti-HCV antibodies, Multiple transfusions.

Article Citation

Akram M, Bajwa Y, Choudhary MN, Asif M. Multiple transfusions; frequency of anti-hepatitis c virus (HCV) in children. Professional Med J 2013;20(5): 684-687.

\section{INTRODUCTION}

Hepatitis is an entity has been recognized for thousands of years. The description of jaundice, i.e. hepatitis, dates of ancient Chinese writings, and the first European reference dates to the third century $A D$. Recognition that hepatitis has an infectious etiology has been in the modern literature since early in last century ${ }^{1}$. Hepatitis C virus (HCV) infection is a major, worldwide health problem ${ }^{2}$. It is estimated that over 170- 200 million people are infected and the virus is distributed worldwide with a prevalence varying in different countries from $0.2 \%$ up to $40 \% \%^{3,4}$. HCV infection has gained importance as one of the major complications in multiply transfused patients as HCV is prevalent among the general population and hence among blood donors ${ }^{5}$.

Thalassemia is one of the most common genetic diseases in the world, causing much morbidity, early mortality and a great deal of misery for a family both financially and emotionally ${ }^{6}$. Thalassemia is the most prevalent hereditary hemoglobin disorder in the world ${ }^{7}$. Screening of blood donors for HCV antibody has decreased the risk of transfusion-associated HCV infection. However our multi-transfused patients are still at risk of acquiring infection due to the large reservoir of $\mathrm{HCV}$ in the community, exposure to subtypes that couldn't be detected by current techniques and blood donation of recently infected persons with negative serological results (window period) ${ }^{8}$.

Regular blood transfusion comprises a major essential for management of thalassemia which puts these patients at a higher risk of developing related complications, among which is transmission of infectious agents in $\mathrm{HCV}^{9}$. Multiply transfused children include patients of leukemia, lymphomas, solid 
tumors, aplastic anemia, thalassemia, sickle cell anemia, hemophilia and bleeding disorders etc. These patients require frequent blood transfusions from multiple donors for their survival, so they are at risk to receive blood from a donor who is already infected with hepatitis $C^{10}$. In Pakistan hepatitis $C$ is reported to be the major type of post-transfusion hepatitis. This disease is frequently encountered in children who require multiple blood transfusion. In this study children coming in various hospitals requiring blood transfusions will be studied for the presence of antiHCV antibody. This study will be helpful in determining the efficiency of the screening being done in our hospitals to reduce the risks of HCV infection.

\section{SUBJECTS AND METHODS}

One hundred blood samples were collected from the children with multiple transfusions. This study was conducted at Shalamar Hospital, Lahore. The samples were collected from Children Hospital, Mayo Hospital and Fatimid Foundation, Lahore between Jan 2012 to June 2012. Samples were collected from children who had received more than two blood transfusions (either whole blood or blood products). Two to three $\mathrm{ml}$ of blood was taken from each multiply transfused child who had received more than two blood transfusions. Serum was separated from each sample by centrifugation at $6000 \mathrm{rpm}$ for 5 minutes. After serum separation, all the samples were stored at $-80^{\circ} \mathrm{C}$. The HCV antibody can be detected by anti-HCV Rapid Test but third or fourth generation enzyme linked immunosorbent assay (ELISA) is considered a better indicator of the seropositivity of this antibody. The enzyme linked immunosorbent assay (ELISA), enzyme immunoassay (EIA) or solid phase immunosorbent assay (SPIA) is a sensitive laboratory method used to detect the presence of antigens or antibodies of interest in wide variety biological samples. It is important during assay optimization, to ensure that the secondary antibodies does not bind non-specifically to the antigens preparation or impurities within it, nor to the solid phase.

\section{RESULTS}

The ages ranged from 6 months to $>12$ years. The children with ages 2-4 years are maximum 27 (27\%) and $\geq 12$ years are minimum 7 (7\%) children. The mean age of children in the study was $6.17 \pm 4.13$ years. Out of the 100 children, $70(70 \%)$ were males and $30(30 \%)$ were females. Male to female ratio is 2.3:1 (Table I). This study showed that thalassemic children are 58 and children with different types of leukemia are 27 while children with aplastic anemia are 11. Two children are with neuroblastoma while one each with thrombobasthenia and CDA-1 (Table II). Forty eight children had 2-25 transfusions while 19 children had 26-50 transfusions, 21 children had 51100 transfusions while 12 children had >100 transfusion (Table III).

\begin{tabular}{|c|c|c|}
\hline Variable & No. & $\%$ \\
\hline \multicolumn{3}{|l|}{ Age years } \\
\hline$<2$ & 19 & 19.0 \\
\hline $2-4$ & 27 & 27.0 \\
\hline $5-8$ & 22 & 22.0 \\
\hline $9-12$ & 25 & 25.0 \\
\hline$>12$ & 7 & 7.0 \\
\hline \multicolumn{3}{|l|}{ Gender } \\
\hline Males & 70 & 70.0 \\
\hline Females & 30 & 30.0 \\
\hline
\end{tabular}

\begin{tabular}{|l|c|c|c|c|}
\hline \multirow{2}{*}{ Disease } & \multicolumn{2}{|c|}{ Reactive cases } & Non-reactive cases \\
\cline { 2 - 5 } & No. & $\%$ & No. & $\%$ \\
\hline Thalasemia $(n=58)$ & 22 & 37.9 & 36 & 62.1 \\
\hline Leukemia $(n=27)$ & - & - & 27 & 10.0 \\
\hline Aplastic anemia $(n=11)$ & 1 & 9.0 & 10 & 91.0 \\
\hline Neuroblastoma $(n=2)$ & - & - & 2 & 10.0 \\
\hline Thrombbasthenia $(n=1)$ & - & - & 1 & 10.0 \\
\hline CDA type-1 $(n=1)$ & - & - & 1 & 10.0 \\
\hline
\end{tabular}




\begin{tabular}{|c|c|c|c|c|}
\hline \multirow{2}{*}{$\begin{array}{c}\text { No. of } \\
\text { Transfusion }\end{array}$} & \multicolumn{2}{|c|}{ Reactive cases } & Non-reactive cases \\
\cline { 2 - 5 } & No. & $\%$ & No. & $\%$ \\
\hline $2-25(n=48)$ & 3 & 6.3 & 45 & 93.7 \\
\hline $26-50(n=19)$ & 5 & 26.5 & 14 & 73.7 \\
\hline $51-100(n=21)$ & 6 & 28.6 & 15 & 71.4 \\
\hline$>100(n=21)$ & 9 & 75 & 3 & 25.0 \\
\hline
\end{tabular}

\section{DISCUSSION}

Early and regular blood transfusion therapy in patients of thalassemia decreases the complications of severe anemia and prolongs survival ${ }^{6}$. This is particularly true in patients who are fortunate enough to receive an adequate, regular iron chelation therapy, and are therefore protected from organ damage by iron overload $^{11}$. Rapid prevalence of hepatitis $\mathrm{C}$ has become a serious problem these days, as a number of patients are diagnosed as seropositive for anti-HCV antibody. It is a major threat to life because no vaccination of this disease has yet been developed, and there is no proper treatment as well. There are multiple reasons for the spread of hepatitis $\mathrm{C}$, but the major factor is transfusion of blood and blood products. Majority of children included in this study were suffering from thalassemia, it shows a very high frequency of $37.9 \%$. In different parts of the world, the prevalence of HCV infection in thalassemic patients differs. Some countries have lower prevalence than that estimated by our study: $32 \%$ in India ${ }^{12}, 13.7 \%$ in Mexico $^{13}$ and $14 \%$ in Lebanon ${ }^{14}$. Others have higher prevalence than ours: $63 \%$ in Saudi Arabia $^{15}, 60 \%$ in $\mathrm{UK}^{16}$ and $85 \%$ in Iran ${ }^{17}$. This variation in results can be attributed to the different total prevalence of HCV infection among the general population, and hence among blood donors, and also to the different types of tests used for HCV antibody detection.

The prevalence of hepatitis $C$ virus antibodies is directly related to the number of transfusions ${ }^{18,19}$. The results of the present study, indicate a greater prevalence of anti-HCV antibody in the patients with greater number of transfusion as in the patients with more than 100 transfusion. This also indicates that frequency of anti-HCV is not related with the type of disease but actually with the number of transfusions. Our study is in favour of the study of Jimnenez et a ${ }^{20}$ who also observed that anti-HCV seropositivity increased proportionally to the number of transfusions. In the present study, ELISA is used to detect the frequency of anti-HCV antibody in multiply transfused children. A high frequency of $23 \%$ is observed, which is quite alarming. Since the prevalence of HCV hepatitis is alarmingly increasing in our population, serious measures have to be undertaken to reduce the spread of HCV infection through awareness campaigns on war footing.

\section{CONCLUSION}

The prevalence of HCV infections are very high among Pakistani thalassemic patients, which calls for a critical look into the prevailing transfusion practices and adoption of stricter donor selection criteria to decrease the incidence rate of both HCV infections effectively. It is concluded that $\mathrm{HBsAg}$ also be done in multi-transfused children and samples must be screened by the most sensitive technique like chemiluminescence and microparticle enzyme immunoassay.

\section{Copyright (C) 18 Apr, 2013.}

\section{REFERENCES}

1. Fonseca JC. History of viral hepatitis. Rev Soc Bras Med Trop 2010;43(3):322-30.

2. El-Beshlawy A, Youssry I. Prevention of Hemoglobinopathies in Egypt. Hemoglobin 2009;33 Suppl 1:S1420.

3. Alavian SM. Hepatitis C infection in Iran; a review article. Iran J Clin Infect Dis 2009;4:47-59.

4. Te HS, Jensen DM. Epidemiology of hepatitis B and C viruses: a global overview. Clin Liver Dis. 2010 Feb;14(1):1-21. 
5. Karimi M, Ghavanini AA. Seroprevalence of hepatitis $B$, hepatitis C and human immunodeficiency virus antibodies among multitransfused thalassemic children in Shiraz. Iran.J Paediatr. Child Health 2001; 37:564-6.

6. Mansour AK, Aly RM, Abdelrazek SY, Elghannam DM, Abdelaziz SM, Shahine DA, Elmenshawy NM, Darwisha AM. Prevalence of HBV and HCV infection among multi-transfused Egyptian thalassemic patients. Hematol Oncol Stem Cell Ther 2012; 5(1): 54-9.

7. Lo L, Singer ST. Thalassemia: current approach to an old disease. Pediatr Clin North Am 2002, 49(6): 116591.

8. Omar NK, Salama S, Adolf N, Ghaffar A, Ezzat N, Soliman G. Prevalence of HCV, HBV, and HIV infection in Egyptian thalassemics. JAC 2009; 20(6): 373-9.

9. Ragab LS, Helal N, Zaghlol M, El-Raziky R, Afifi S Clinicovirologic analysis of hepatitis $C$ infection in transfusion-dependent-thalassemia major children. International Journal of Laboratory Hematology 2010; 32(2): $184-90$.

10. Alter HJ. Transmission patterns in hepatitis $\mathbf{C}$ virus. In: Nishioka K, Suzuki H, Mishiro S, Oda T, editiors. Viral hepatitis and liver disease. Tokyo: Springer-Verlag, 1994;445-9.

11. Prati D. Benefits and complications of regular blood transfusion in patients with beta-thalassemia major. Vox-Sang 2000; 79(3): 129-37.

12. Madhusudhan K, Thyagarajan SP. Seroprevalence of hepatitis $\mathrm{C}$ virus markers in multi-transfused children with beta-thalassemia. BMC Infectious Diseases 2012; 12(Suppl 1):42-7.

AUTHOR(S):

1. MR. MUHAMMAD AKRAM

Assistant Professor Biochemistry

SFINHS, Shaikh Zayed Medical Complex Lahore.

2. MR. YOUNAS BAJWA

3. PROF. DR. M. NAWAZ CH.

4. Dr. Muhammad Asif

Lecturer Pathology

KMU Institute of Medical Sciences Kohat (KPK).
13. Calderón GM, González-Velázquez F, González-Bonilla CR, Novelo-Garza B, Terrazas JJ, Martínez-Rodríguez $\mathrm{ML}$, et al. Prevalence and risk factors of hepatitis C virus, hepatitis B virus, and human immunodeficiency virus in multiply transfused recipients in Mexico. Transfusion 2009;49(10):2200-7.

14. Ramia S, Koussa S, Taher A, et al. Hepatitis-C virus genotypes and hepatitis-G-virus infection in Lebanese thalassaemics. Ann Trop Med Parasitol 2002; 96(2): 197-202.

15. Alavian SM, Tabatabaei SV, Lankarani KB. Epidemiology of HCV infection among Thalassemia patients in eastern Mediterranean countries: a quantitative review of literature. IRCMJ 2010; 12 : 365-76.

16. Allain JP. Occult hepatitis B virus infection: implications in transfusion. Vox Sang 2004;86(2):8391.

17. Ameli M, Besharati S, Nemati K, Zamani F. Relationship between elevated liver enzyme with iron overload and viral hepatitis in thalassemia major patients in Northern Iran. Saudi Med J 2008;29(11):1611-5.

18. Luban NL, Colvin CA, Mohan P, Alter HJ. The epidemiology of transfusion-associated hepatitis $\mathrm{C}$ in a children's hospital. Transfusion 2007;47(4):615-20.

19. Issa H. Safety of pegylated interferon and ribavirin therapy for chronic hepatitis $\mathbf{C}$ in patients with sickle cell anemia. World J Hepatol 2010;2(5):180-4.

20. Jimnenez FP, Fuentes M, Borbolla BE. Anti-HCV in patients transfused, in a health area attended by a family physician. Acta Gastroenterol Latinom 2000; 30(2): 99-105.

Correspondence Address:

Dr. Muhammad Akram

Assistant Professor Biochemistry

SFINHS, Shaikh Zayed Medical Complex Lahore.

aakramskzmdc@yahoo.com 